\title{
BULLYING TERHADAP SENIOR DAN JUNIOR FILSAFAT MANUSIA
}

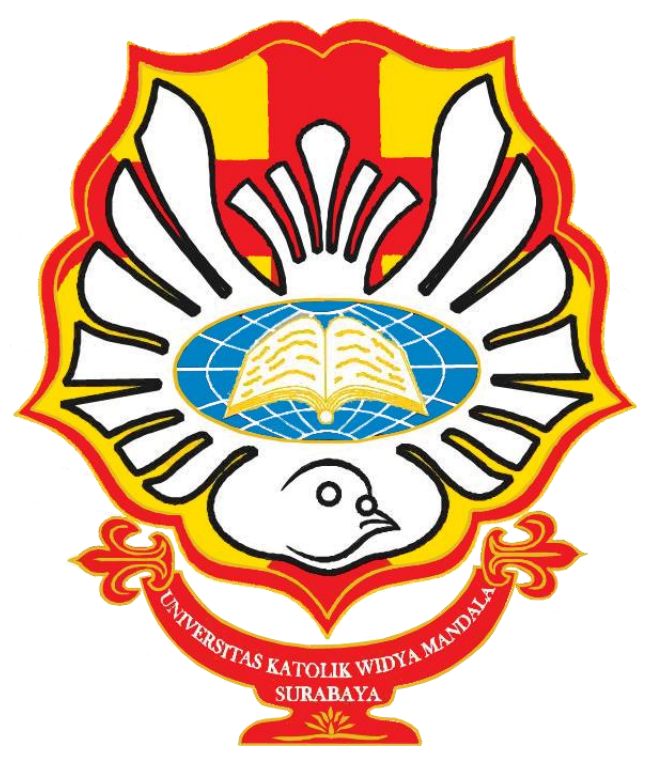

Ditulis oleh:

Kurniawan Setyo Budi Santoso (41417008)

\section{FAKULTAS TEKNIK \\ PROGAM STUDI TEKNIK INDUSTRI \\ UNIVERSITAS KATOLIK WIDYA MANDALA SURABAYA KAMPUS MADIUN}




\begin{abstract}
Abstrak
Kasus bullying masih sering terjadi dikalangan remaji tidakan ini dilakukan secara disengaja maupun tidak disengaja, tindakan kejahatan tersebut menyerang mentalitas sesorang hingga stress dan depresi yang berkelanjutan. Pada kasus kali ini bullying terjadi di suatu instansi dengan alasan mengikuti suatu kegiatan yang diwajibkan sehingga bullying terjadi hingga menimbulkan korban. Bullying terjadi karena modus balas dendam yang berkelanjutan hingga turun temurun, sehingga bullying masih sering terjadi.
\end{abstract}

Keyword: Bullying, Filsafat Manusia

\title{
I. Pendahuluan
}

Bullying adalah tindakan di mana satu orang atau lebih mencoba untuk menyakiti atau mengontrol orang lain dengan cara kekerasan. Ada banyak jenis bullying. Bisa menyakiti dalam bentuk fisik, seperti memukul, mendorong, dan sebagainya. Dalam bentuk verbal adalah menghina, membentak, dan menggunakan kata-kata kasar. Bullying dalam bentuk sosial seperti mengucilkan, dan mengabaikan orang. Di jaman yang serba teknologi ini bullying pun bisa melalui gadget, dan media sosial yang disebut Cyberbullying. Cyberbullying adalah saat seseorang dihina-hina, diteror di media sosial, atau melalui SMS, email, dan telepon. Contoh bullying yang paling sering ditemui disekitar kita adalah kakak kelas melabrak adik kelas karena dinilai bertingkah. Masa orientasi siswa yang berakhir buruk karena si kakak kelas berlebihan mengerjai para siswa baru. Teman sekelas yang dianggap aneh dikucilkan, dan tidak ada yang mau berteman dengannya

Para pelaku bully mendapatkan kepuasan dari menindas orang. Ia merasa lebih kuat, lebih berkuasa, karena ada orang yang takut pada dirinya. Bisa jadi ia berpikiran, ia akan mendapat popularitas disekolah karena ditakuti oleh siswa lainnya. Padahal sesungguhnya para pembully ini akan dibenci oleh orang-orang yang tidak setuju dengan tindakannya. 
Dan alasan lain mereka menindas adalah karena mereka iri pada kelebihan target bullying mereka, mereka merasa terancam dengan kehadiran seseorang yang lebih cantik, lebih pintar dari mereka. Atau sebenarnya mereka memiliki masalah yang menyebabkan mereka menindas untuk menyalurkan amarah mereka kepada orang lain. Mereka tidak tahu apa dampak perbuatan bullyingnya terhadap para korban mereka. Sehingga mereka tidak merasa bersalah atas perbuatannya.

Orang yang biasanya dijadikan target penindasan adalah orang yang memiliki perbedaan mencolok dibanding yang lain. Perbedaan ini bisa jadi dari fisik, agama, rasnya, bahkan gaya berpakaian, dan perilaku seseorang. Contoh yang paling sering ditemui adalah kakak kelas tidak suka dengan adik kelas yang 'bertingkah' karena mencolok secara fisik, gaya berpakaian, dan perilaku sehingga dilabrak habis-habisan. Hal ini menyebabkan para adik kelas merasa takut berkeliaran, dan bertindak disekitar sekolah.

Dampak dari bullying adalah membuat para korban merasa benci terhadap dirinya sendiri, mereka merasakan ketakutan menghadapi dunia luar sehingga mereka mengurung diri dirumah, mereka juga akan merasa depresi,dan stress yang mempengaruhi kesehatan mereka. Yang paling parah adalah mereka memutuskan untuk bunuh diri karena tidak tahan lagi.

Para penyiksa sebenarnya juga mendapatkan dampak dari perilakunya. Menurut survey kebanyakan besar dari orang yang dulunya penyiksa dimasa sekolah akan melakukan tindakan kriminal saat dewasa. Mereka juga akan kesulitan menjalin hubungan pertemanan dengan teman sekolahnya. Begitu mereka dewasa nanti mereka juga akan sulit beradaptasi dengan teman-teman kerjanya karena ia terbiasa mengontrol orang lain.

Sama hal nya seperti kasus yang di unggah dimedia social detiknews bullying kakak kelas terhadap adik kelas di SMA 90 Jakarta. Lapangan di kawasan Bintaro menjadi saksi bisu aksi kekerasan yang terjadi di SMA tersebut. Siswa kelas 1 dipaksa buka baju, push up, lari dan di tampar. 
“dibawa kakak kelas dari pakiran diasana merak disuruh melakukan push up, buka baju, dan lari. Disana juga disuruh melakukan suit dimana yang kalah mendapatkan tamparan yang keras kegiatan tersebut dilakukan waktu zuhur hingga ashar." Kata Aba.

Hal ini disampaikan Aba di SMA 90 Jakarta, J1 Sabar, Petukangan Selatan, Pesanggrahan, Jakarta Selatan, Senin (1/12/2008). Aba mengalami luka bibir pecah, memar di pelipis.

Dikatakan dia, sedikitnya 68 siswa kelas 1 dari 9 kelas dipaksa ikut 'penataran.' "Disuruh kelas 2 dan 3, katanya untuk penataran," ujarnya.

Menurut Aba, ada juga teman-temannya yang dibawa ke lantai 3 sekolah. "Tetapi nggak tahu diapain. Biasanya jam-jam istirahat. Dengar dari anak-anak cuma dikasih tahu, anak kelas 1 parkir di belakang," tutur Aba.

SMA 90 lantas menskorsing 31 siswanya yang terlibat bullying selama 5 hari. Para senior menandatangani surat perjanjian di atas materai agar tidak mengulangi perbuatannya. 


\section{Teori}

Dalam kasus ini saya mengkaitkan dengan teori tentang Dimensi Dasar Manusia, dimana dimensi dasar manusia meliputi: bahasa, sosialitas, historitas, dan kejasmanian. Tetapi disini saya mengambil tentang sosialitas, historitas, dan kejasmanian.

A. Sosialitas

a. Fenomena Sosial

Sosialitas mengadung di dalamnya sistem social. Didalam sistem ini terjadilah berbagai bentuk relasi sosial, semua orang terlibat dalam berbagai bentuk relasi tersebut. Ada relasi yang bersifat kodrati, tetapi ada juga yang buatan. Fenomena sosial kerap dimaknai sebagai segala sesuatu yang berhubungan dengan fakta sosial. Secara genetis sudah ada factor pembentuk tingkah laku manusia, baik itu egoistis maupun altruistik. Sosiobiologi dilatarbelakangi oleh materialism, sehingga kodrat manusia disamakan begitu saja dengan kodrat biologis (turunan), padahal manusia memilik kemampuan belajar Sosiobiologi perlu diimbangi oleh sosiologi (yang terlepas dari biologi), dan filsafat sosial yang meneliti hakekat dan pemaknaan secara komprehensif.

b. Dua Posisi Ekstrim dalam Sosiolitas

i. Individualisme: Nilai utama yang dijunjung adalah individu, dan kebersamaan adalah nilai sekunder. Pendasaran ontologisnya: individu adalah relitas hakiki sejak adanya manusia (bukan kebersamaan). Kebersamaan muncul kemudian (aksidental). Hak pribadi itu utama, dan setiap individu berkuasa atas dirinya

ii. Kolektivisme: kebersamaan (keseluruhan) ada lebih dulu dan bersifat absolut. Pendasaran otologisnya: realitas sosial tidak diasalkan dari individu. Realitas sosial memilik memilik 
realtias adanya sendiri. Kepentingan bersama lebih penting dari kepentingan pribadi.

Dalam kasus ini saya mengkaitkan dengan teori Fenomena Sosialitas dimana terjadi berbagai bentuk relasi sosial, semua orang terlibat dalam berbagai bentuk relasi tersebut. Ada satu provokasi antar senior untak melakukan tindakan perpeloncoan atau bullying dimana kegiatan tersebut sudah direncanakan apa yang akan dilakukan saat didepan para junior. Kegiatan tersebut biasa dilaksanaakan di dalam suatu organisasi, pada kasus ini sejumlah adik kelas di paksa untuk mengikuti kegiatan penataran namun kegatan tersebut dilakukan tidak secara terbuka apa saja bentuk kegiatan yang akan dilakukan sehingga peserta tidak tau kegiatan atau materi apa yang akan di berikan kepada peserta dan para guru pendamping pun tidak mengetahui kegiatan tersebut sehingga tidak ada pengawasan ketat. Jadi menurut saya bentuk relasi yang di jalan kan adalah relasi negatif, dimana relasi untuk melakukan tindak kejahatan (bullying) hingga melakukan tindakkan kekerasan kepada peserta penataran.

B. Historitas (Kesejahterahan)

a. Penulisan Sejarah

Historitas adalah penggangu dan sekaligus pendukung. Ia adalah pengganggu karena mengingat mansiua pada masa lalu. Ia bisa juga pendukung karena di dalam kesejarahan tersebut terjadi realisasi khas masing-masing manusia. Ilmu sejarah itu posisinya sama dengan ilmuilmu empiris yang lain. Penulisan sejarah harus tunduk pada objektivitas. Sejarah harus selalu direkontruksi, karena ia tidak seratus persen mewakili seluruh fakta. Sejarah harus dikaji ulang, karena bisa jadi penyimpulan masa lalu itu tergesa-gesa, dan setiap sumber tertulis tidak akan pernah tuntas mengutarakan sesuatu. Bukankah setiap tulisan adalah penafsiran? Sesorang sejarawan harus kritis terhadap tulisannya sendiri. Ia juga harus melibatkan disiplin ilmu lain 
b. Waktu Objektif dan Waktu Subjektif

Waktu adalah keseluruhan masa lampau, masa kini, dan masa depan. Masa sekarang adalah sintese masa lampau dan masa depan, karena masa lampau hadir dalam kenangan dan masa depan hadir dalam bentuk antisipasi. Masa sekarang menempati peran penting karena subjek bergiat dengan kekiniannya lewat mengenang dan mengatisipasi.

Waktu subjektif adalah waktu yang melekat pada subjek, karena tanpa subjek tidak ada kesadasaran akan waktu. Waktu adalah produk subjek dan sekaligus tidak bisa dimengerti tanpa subjek. Waktu dengan demikian adalah jalinan antara waktu objektif dan subjektif. Waktu menjadi subjektif jika masuk kedalam kesadaran subjek. Waktu itu juga objektif karena memilik strutur tersendiri terlepas dari subjek. Dengan demikian, masa depan adalah kemungkinanku, masa lamapu adalah keharusanku, dan masa lampau adalah sesuatu yang belum harus aku lengkapi.

Pada kasus yang saya ambil, saya mengkaitkan dengan materi tentang dimensi dasar manusia sub bab historitas (kesejarahan). Dimana para senior melukan kegiatan penataran untuk melakukan aksi bullying terhadap para junior mereka. Kegiata bullying dilaksanakan dilandaskan historitas para senior mereka dahulu dan dilampiaskan kepada senior mereka yang baru. Sejarah meupakan penggangu pikiran yang mengingatkan kejadian yang mereka alami di masa lampau dimana para senior sekarang juga di berlakukan sama seperti senior mereka yang dahulu, dan para senior sekarang meneruskan tindakan tidak terpuji kepada para junior mereka. Dalam teori "peristiwa masa lalu yang dihadirkan sekarang dilakukan di atas satu ide tentang waktu objektif. Dimana waktu objektif adalah struktur waktu dimana suatu peristiwa terjadi atau sudah yang lain. Ada waktu yang di buat berdasarkan kesepakatan.” Tetapi dalam kasus ini diangkat lagi atas masalalu para senior yang dilandaskan satu pemikiran atas para senior lain dimana pemikiran tersebut untuk melancarkan kegiatan tidak baik ini. Tanpa kesepakatan ide antar 
para senior untuk melakukan tersebut, maka kegiatan bullying yang sampai melakukan tindakan kekerasan tidak akan pernah terjadi.

\section{Argumentasi}

Menurut saya pada kasus bullying pada SMA 90 Jakarta dapat dicegah bahkan dapat tidak terlaksana. Kasus ini terjadi atau timbul dari dalam diri masing-masing yang berlandas kan cemburu sosial sehingga mendukung tindakan bullying yang teprokasi oleh satu pihak dan yang lain menyetujui tindakan tersebut. Kegiatan yang tidak seharusnya terjadi dapat diminimalisir dengan sikap kedewasaan antar pribadi masing-masing individu. Jangan jadikan sebuah punishment atau hukuman sebagai alat untuk melakukan bullying, jangan jadaikan masa lampau yang telah terjadi pada diri kita atau kelompok kita sebagai sifat turun-tumurun. Kegiatan bullying tindakan sangat tidak dianjurkan karena korban dapat merasa benci terhadap dirinya sendiri, mereka merasakan ketakutan menghadapi dunia luar sehingga mereka mengurung diri dirumah, mereka juga akan merasa depresi,dan stress yang mempengaruhi kesehatan mereka, yang paling parah adalah mereka memutuskan untuk bunuh diri karena tidak tahan lagi akibat bullying secara berlebihan.

Jadikan pribadi kita menjadi dewesa dalam hal pemikiran, pikirkan dampak yang akan terjadi sebelum kita melakukan sesuatu apakah merugikan orang lain? Bullying dapat dicegah dari diri kita sendiri. Berawal dari diri kita semua tindak kejahatan tidak akan terjadi.

Kepada instansi diharapkan untuk selalu mengawasi dan memperhatikan setiap kegiatan yang mengatas namakan sekolah jangan sampai kegiatan bullying terjadi kembali hingga memakan korban. 


\section{Daftar Pustaka}

https://cewekbanget.grid.id/read/06852829/apa-sih-bullying-itu?page=all

https://news.detik.com/berita/d-1979089/5-kasus-bullying-sma-dijakarta/2\#detailfoto

Dewantara, Agustinus. "Filsafat Manusia (Dimensi Dasar Manusia)." (2019). 